COMMENTARY ON COVID-19 AND THE FoOd SYSTEM

\title{
COVID-19 amplifies local meat supply chain issues in South Carolina
}

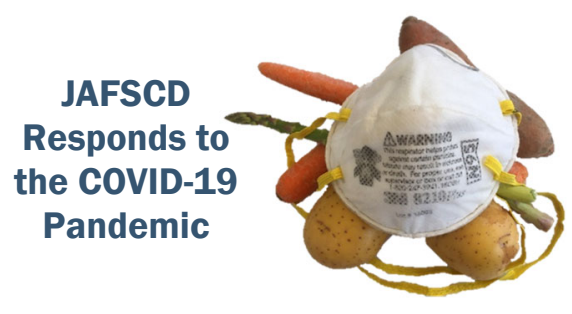

Steven Richards a*

Clemson Cooperative Extension

Michael Vassalos ${ }^{b}$
Clemson University

Submitted August 23, 2020 / Published online October 8, 2020

Citation: Richards, S., \& Vassalos, M. (2020). COVID-19 amplifies local meat supply chain issues in South Carolina. Journal of Agriculture, Food Systems, and Community

Development, 10(1), 191-195. https://doi.org/10.5304/jafscd.2020.101.001

Copyright $(C) 2020$ by the Authors. Published by the Lyson Center for Civic Agriculture and Food Systems. Open access under CC-BY license.

$\mathrm{B}$ efore COVID-19, livestock producers across the U.S. had been complaining to Congress about a lack of meat processing options closer to their farms (Swanson, 2015). Publications used examples of farmers shipping their animals hundreds of miles to be processed (Miles, 2012) and placed the blame on the U.S. Department of Agriculture (USDA) and industry regulations (Linnekin, 2016). Others have warned that decades of consolidation of meat-processing facilities have left fewer reliable options for livestock farmers, threatening the farm-to-table economy (Shanker, 2017).

The COVID-19 pandemic amplified these issues starting in April 2020, when U.S. meat packers shut down or scaled back operations to reduce the spread of COVID-19 among their workers. The resulting

\footnotetext{
a * Corresponding author: Steven Richards, Agribusiness Extension Associate, Clemson Cooperative Extension; 18 John Galt Road; Beaufort, South Carolina 29906 USA; +1-843-473-6024; Stricha@,clemson.edu

b Michael Vassalos, Associate Professor of Agribusiness, Clemson University; Mvassal@clemson.edu
}

\section{Author Note}

Steven Richards and Clemson's Agribusiness, Livestock and Forages, and Food Systems and Safety Teams will be leading the local meat supply chain study in South Carolina.

\section{Funding Disclosure}

Funding for this study will be provided by the Berkeley Electric Cooperative, the South Carolina Cattlemen's Association, and the South Carolina Power Team. 
dip in U.S. meat-packing volumes led grocery store chains to limit the amount of meat customers could buy (Guzman, 2020), and some hamburger restaurants actually had to take hamburgers off their menus (Stump, 2020). Both livestock producers and consumers experienced panic during this time. Worried that the U.S. was running out of meat, consumers started a meat-buying frenzy. In the meantime, animals ready for processing had nowhere to go, causing livestock farmers to lose money or, even worse, euthanize their animals (Repko \& Lucas, 2020).

On April 28, 2020, President Trump signed an executive order mandating that U.S. meat processors were critical infrastructure and must remain open (Faulders, 2020). Most processing operations complied with this order, and a more dramatic shortage in the nation's meat supply was largely avoided (Bagentose, 2020; Conner, 2020). As a consequence of this close call, U.S. meat prices rose in response to the contraction in supply (Lusk, 2020), and prices remain high. Retail meat prices through the end of May 2020 show year-over-year beef prices up $21.7 \%$, pork prices up $17.7 \%$, and chicken prices up $10.5 \%$ (Bunge \& Kang, 2020). Wholesale ground beef saw the largest price jump in May, increasing more than $100 \%$ from its mid-March price (Bunge \& Kang, 2020). The August USDA Meat Price Spreads report shows that prices remain elevated for all three meats (USDA Economic Research Service, 2020).

\section{South Carolina's Situation}

South Carolina's situation reflects what is occurring in many other states. The threat of a national shortage and surging retail meat prices have spiked demand for local meat products. Local livestock producers have been swamped with calls from customers wanting to buy their meat products. In South Carolina, this golden marketing opportunity hit an obstacle when farmers called local processors and found that they were backlogged by six to nine months (M. Filion \& B. Bowers, personal communication, July 28, 2020).

South Carolina livestock producers are currently petitioning for more processing facilities. And, while more processing capacity is needed, enhancing an entire supply chain involves a more comprehensive solution, as evidenced by past feasibility studies and research.

\section{What Do Past Studies Feasibility Studies Tell Us?}

Dozens of feasibility studies on local livestock processing have been performed across the U.S. (Table 1), and rarely did a new processing facility result, even if it was feasible. This is most likely a reflection of high investment costs, with a small, bare-bones facility starting at US\$1 million (Niche Meat Processor Assistance Network [NPMAN], 2016). Another reason could be that some of these studies did not address the entire local meat supply chain. The literature would suggest that at least seven components of the local meat supply chain need to be researched to find comprehensive solutions.

1. Producer Supply: Surveying livestock producers to determine how many animals are available for processing each year and if producers plan on raising more animals in the future.

2. Logistics: Mapping current processing plants in relation to locations with the highest concentration of animals.

3. Aggregation: Exploring ways for producers to aggregate animals in batches, as most processors are dependent on a consistent supply of animals (Gwin, Thiboumery, \& Stillman, 2013).

4. Addressing Inspection Systems: Many states have both state and federal meat inspection systems. In South Carolina, the two inspection systems have equal standards, but state-inspected meat products cannot be shipped across state lines, limiting the marketing area for some producers.

5. Slaughter and Processing Capacities: Surveying current processors to discover what capacity constraints exist and are the most critical. 
6. Storage and Distribution: Assessing the local meat supply chain's cold and frozen storage and distribution capacity.

7. Consumer Demand: Surveying consumers' preferences for local meat and willingness to pay a premium. A consumer survey would also be useful to assess if the COVID-19 events described have caused a structural or temporary change in local meat demand.

\section{Lessons Learned}

A 2013 USDA study sums up the problem nicely: a lack of commitment and coordination along the entire supply chain is the primary reason local meat processing has not expanded (Gwin et al., 2013). Another study of 20 years of public investment into meat and poultry processing provides valuable tips on how to structure a comprehensive study and which investment projects are most likely to succeed (Gwin \& Thistlethwaite, 2019). A holistic approach is needed to address the complex local meat supply chain, and a feasibility study that only addresses slaughter facilities is likely to fall short. While producers in South Carolina and across the U.S. are anxious to build additional meat-processing facilities, a welldesigned supply chain study will likely provide more viable options for local meat producers, processors, and consumers.

Table 1. Components of Past Feasibility Studies by Location and Year

\begin{tabular}{|c|c|c|c|c|c|c|c|}
\hline Study & $\begin{array}{c}\text { Producer } \\
\text { Supply }\end{array}$ & $\begin{array}{c}\text { Aggregation \& } \\
\text { Logistics }\end{array}$ & $\begin{array}{c}\text { Inspection } \\
\text { Systems }\end{array}$ & $\begin{array}{c}\text { Slaughter } \\
\text { Capacity }\end{array}$ & $\begin{array}{l}\text { Processing } \\
\text { Capacity }\end{array}$ & $\begin{array}{c}\text { Storage \& } \\
\text { Distribution }\end{array}$ & $\begin{array}{l}\text { Consumer } \\
\text { Demand }\end{array}$ \\
\hline CT, $2008^{a}$ & Yes & No & Yes & Yes & Yes & No & No \\
\hline WI, 2019b & Yes & No & Yes & Yes & Yes & No & No \\
\hline MI, $2014^{c}$ & No & No & Yes & Yes & Yes & Yes & No \\
\hline Australia, $2017^{d}$ & Yes & Yes & $\mathrm{N} / \mathrm{A}$ & Yes & Yes & Yes & No \\
\hline NY, $2000^{e}$ & Yes & Logistics only & Yes & Yes & Yes & Yes & No \\
\hline MD, $2006^{f}$ & Yes & Logistics only & Yes & Yes & Yes & Yes & No \\
\hline VT, $2005^{\mathrm{g}}$ & Yes & Yes & Yes & Yes & Yes & No & No \\
\hline $\mathrm{NC}, 2012^{\mathrm{h}}$ & Yes & No & Yes & Yes & Yes & No & Yes \\
\hline MT, 2006 & Beef only & Yes & Yes & Yes & Yes & Yes & Wholesale only \\
\hline$C A, 2009^{j}$ & Yes & Yes & Yes & Yes & Yes & Yes & Yes \\
\hline MA, $2013^{k}$ & Yes & Yes & Yes & Yes & Yes & Yes & Yes \\
\hline MI, 2007' & Yes & Yes & Yes & Yes & Yes & Yes & Yes \\
\hline VA, $2014^{m}$ & Yes & Yes & Yes & Yes & Yes & Yes & Yes \\
\hline $\mathrm{GA}, 2019^{n}$ & Beef only & Yes & Yes & Yes & Yes & Yes & Yes \\
\hline
\end{tabular}

Notes: a Community Involved in Sustaining Agriculture [CISA], 2008; b Grooms, 2019; c Schweihofer, Wells, Miller, \& Pirog, 2014;

d Australian Competition \& Consumer Commission, 2017; e Shepstone, 2000; ${ }^{f}$ Shepstone, 2006; g Sleeping Lion Associates, 2005;

h ASAP Local Food Research Center, 2012; i Food and Livestock Planning, 2006; j Hardesty et al., 2009; k Dickenson, Joseph, \& Ward, 2013; ' Knudson \& Peterson, 2007; ' Matson Consulting, 2014; n Wolfe, Shephard, \& Kane, 2019

\section{References}

ASAP Local Food Research Center. (2012). Large animal meat processing feasibility in western North Carolina. Retrieved from https://asapconnections.org/research-reports/

Australian Competition \& Consumer Commission. (2017). Cattle and beef market study-Final report. Retrieved from https://www.accc.gov.au/publications/cattle-and-beef-market-study-final-report 
Bagentose, K. (2020, June 16). As leaders warned of US meat shortages, overseas exports of pork and beef continued.

USA Today. Retrieved from https://www.usatoday.com/story/news/investigations/2020/06/16/meat-shortageswere-unlikely-despite-warnings-trump-meatpackers/3198259001/

Bunge, J., \& Kang, J. (2020, May 31). Meat plants reopen, but burgers stay pricey. The Wall Street Journal. Retrieved from https://www.wsj.com/articles/meat-plants-reopen-but-burgers-stay-pricey-11590933601

Community Involved in Sustaining Agriculture [CISA]. (2008). Demand and options for local meat processing: Finding the way from pasture to market in the CT River V alley. Retrieved from https://www.nichemeatprocessing.org/connecticut-river-valley-2008/

Conner, K. (2020, June 12). Is there still a meat shortage? The current situation with chicken, beef, pork prices and supply. CNET. Retrieved from https://www.cnet.com/health/is-there-still-a-meat-shortage-the-current-situationwith-chicken-beef-pork-prices-and-supply/

Dickenson, E., Joseph, S., \& Ward, J. (2013). Confronting challenges in the local meat industry: Focus on the Pioneer Valley of Western Massacbusetts. Community Involved in Sustaining Agriculture (CISA). Retrieved from https://www.buylocalfood.org/local-meat-processing-study/

Faulders, K. (2020, April 28). Trump signs executive order to keep meat processing plants open under Defense Production Act. $A B C$ News. Retrieved from https://abcnews.go.com/Politics/trump-sign-executive-order-meat-processing-plants-open/story?id=70389089

Food and Livestock Planning, Inc. (2006). Feasibility of a beef processing plant in Beaverhead County, Montana. Retrieved from https://growmontana.ncat.org/wp-content/uploads/2014/06/feasibility beef processing dillon.pdf

Grooms, L. (2019, April 11). Study reveals meat-processing needs. Agri-view. Retrieved from https://www.agupdate.com/agriview/news/business/study-reveals-meat-processing-needs/article_56f584ab-36d2$\underline{5310-958 d-e 7 f 25 e e 67199 . h t m l}$

Guzman, J. (2020, May 5). The meat shortage has arrived: Grocers limit meat purchases as coronavirus threatens supply. The Hill. Retrieved from https://thehill.com/changing-america/resilience/natural-disasters/496135-grocers-limitmeat-purchases-as-coronavirus

Gwin, L., \& Thistlethwaite, R. (2019). Lessons learned from public investment in local and regional meat and poultry processing activities (USDA Agricultural Marketing Service Briefing Paper). Retrieved from https://www.nichemeatprocessing.org/nmpan-research/

Gwin, L., Thiboumery, A. \& Stillman, R. (2013). Local meat and poultry processing: The importance of business commitments for long-term viability (USDA Economic Research Service Report No. 150). Retrieved from https://www.ers.usda.gov/publications/pub-details/?pubid=45095

Hardesty, S., Harper, J., Kusunose, Y., Doran, M., Larson, S., Becchetti, T., . . Wright, E. (2009). Meat industry capacity and feasibility study of the north coast region of California. University of California Cooperative Extension Mendocino County \& University of California Davis Department of Agricultural and Resource Economics. Retrieved from https://ucanr.edu/sites/placernevadasmallfarms/Livestock/Niche Meat and Processing/Processing/

Knudson, W. A., \& Peterson, H. C. (2007). A feasibility assessment of a meat slaughtering/processing plant or feedlot in northern Michigan. Retrieved from Michigan State University website: https://www.cant.msu.edu/resources/a-feasibilityassessment-of-a-meat-slaughtering-processing-plant-or-feedlot-in-northern-michigan

Linnekin, B. J. (2016). Biting the hands that feed us: How fewer, smarter laws would make our food system more sustainable. Washington, D.C.: Island Press. https://doi.org/10.5822/978-1-61091-676-9

Lusk, J. (2020, June 17). Domestic meat shortages and exports [Blog post]. Retrieved from http://jaysonlusk.com/ Matson Consulting. (2014). Feasibility study for a USDA inspected meat processing facility for Halifax County. Virginia Foundation for Agriculture, Innovation \& Rural Sustainability. Copy in possession of first author. 
Miles, L. (2012, August 1). More slaughter plants needed for locally sourced meat. Sheep Industry News. Retrieved from https://sheepusa.org/blog/newsmedia-sheepindustrynews-pastissues-2012-august2012moreslaughterplantsneededforlocallysourcedmeat

Milman, O. (2020, May 5). Wendy's pulls burgers off the menu at some locations due to meat shortage. The Guardian. Retrieved from https://www.theguardian.com/environment/2020/may/05/wendys-burgers-beef-meat-shortage-coronavirus

Niche Meat Processor Assistance Network [NPMAN]. (2016). Crash course: Meat processing 101: Small plant economics [Fact sheet]. Retrieved from https://www.nichemeatprocessing.org/beginners-guide-to-local-meat-processing/

Repko, M., \& Lucas, A. (2020, May 7). The meat supply chain is broken. Here's why shortages are likely to last during the coronavirus pandemic. $C N B C$. Retrieved from https://www.cnbc.com/2020/05/07/heres-why-meat-shortages-are-likely-to-last-during-the-pandemic.html

Schweihofer, J., Wells, S., Miller, S., \& Priog, R. (2014). Michigan meat processing capacity assessment final report. Michigan State University Center for Regional Food Systems. Retrieved from https://www.canr.msu.edu/resources/mi-meat-processing-report

Shanker, D. (2017, May 23). There aren't enough slaughterhouses to support the farm-to-table economy. Bloomberg News. Retrieved from https://www.bloomberg.com/news/articles/2017-05-23/there-aren-t-enough-slaughterhouses-tosupport-the-farm-to-table-economy

Shepstone Management Company. (2000). Hudson V alley livestock marketing task force meat processing facility feasibility study. Retrieved from http://www.shepstone.net/HVreport.pdf

Shepstone Management Company. (2006). Southern Maryland livestock producers: Meat processing feasibility study. Retrieved from http://shepstone.net/agricultural-economic-development/

Sleeping Lion Associates. (2005). Slaughterhouse feasibility report. Retrieved from https://ucanr.edu/sites/placernevadasmallfarms/files/107066.pdf

Swanson, A.F. (2015, October 15). Small meat producers take their slaughterhouse gripes to Congress. NPR The Salt. Retrieved from https://www.npr.org/sections/thesalt/2015/10/15/448942740/small-meat-producers-take-theirslaughterhouse-gripes-to-congress

U.S. Department of Agriculture Economic Research Service [USDA ERS]. (2020, August 12). Meat price spreads: Retail prices for beef, pork, and poultry cuts, eggs, and dairy products. Retrieved from https://www.ers.usda.gov/data-products/meat-price-spreads.aspx

Wolfe, K., Shephard, T., \& Kane, S. (2019). Feasibility of Georgia branded beef and local processing in Georgia. Center for Agribusiness and Economic Development, University of Georgia. Copy in possession of the first author. 